\title{
CORRECTION OF IODINE DEFICIENCY STATES AND DYNAMIC MODELING OF POSITIVE DYNAMICS OF INDICATORS OF THYROID FUNCTIONS BY SUPPLEMENTATION
}

\author{
Olesya Horlenko \\ Department of Pediatrics \\ State University "Uzhhorod National University" \\ 3 Narodna sq., Uzhhorod, Transcarpathian region, Ukraine, 88000 \\ ohorlenko@gmail.com \\ Lubov Pushkash \\ Department of Pediatrics \\ State University "Uzhhorod National University" \\ 8 Brashchaiciv str., Uzhhorod, Ukraine, 88000 \\ Oleg Devinyak \\ Department of Pharmaceutical disciplines \\ State University "Uzhhorod National University" \\ 3 Narodna sq., Uzhhorod, Transcarpathian region, Ukraine, 88000 \\ Ivan Pushkash \\ Department of General Surgery with Traumatology and \\ Orthopedics, Operative Surgery, Forensic Medicine \\ State University "Uzhhorod National University" \\ 3 Narodna sq., Uzhhorod, Transcarpathian region, Ukraine, 88000
}

\begin{abstract}
The problem of iodine deficiency diseases (IDD) is recognized as relevant due to the significant prevalence of iodine deficiency among the population of many countries of the world, an increase in the incidence of diseases with a wide range of clinical manifestations and a marked tendency to increase the frequency and severity of IDD among children of all age groups

We carried out a clinical-anamnestic examination of the child's contingent (187 persons) aged 13-17 years living in an ecologically dependent biogeochemical endemic zone of iodine deficiency, the mountain region of the Zakarpattya region during the period from 2014 to 2015 . To identify the pathology of the thyroid gland, a palpatory method of examination was used according to the methodology of the WHO/MRKIDZ, 2001. According to our data 80 pupils (42.8\%) had increased thyroid gland of 1 degree, they were allocated for further and detailed examination and identification of environmentally caused somatic effects. Preventive measures included taking the dietary supplement Yosen, the manufacturer of TOV “OmniFarm”, TU U 10.8-35758392-004: 2014 for 6 months. A statistical model for forecasting the dynamics of TSH with supplements with iodine and selenium has been developed. According to our data, the degree of positive changes (decrease of TSH, increase of T4) with supplements with iodine and selenium depends on the starting content of the microelement of iodine in plasma and/or urine: the lower is the initial level of iodine - the more pronounced is the effect of supplements.
\end{abstract}

Keywords: children, ecologically dependent biogeochemical zone, functional parameters of the thyroid gland.

\section{Introduction}

Beginning with perinatal development and throughout life, a person is under constant influence of geochemical factors of the environment $[1,2]$. The problem of iodine deficiency diseases (IDD) is recognized as relevant due to the significant prevalence of iodine deficiency among the population of many countries in the world, an increase in the incidence of a large range of clinical manifestations and a marked tendency to increase the frequency and severity of IDD among children of all age groups, which causes the problem not only medical, but also socially significant $[3,4]$. 
Disorders of thyroid function occur due to microelemental insufficiency, which can be prevented and eliminated by supplements with the corresponding microelements - iodine and selenium [5]. In the case of endemic causes of iodine deficiency, supplements should cover a significant part of the inhabitants of the respective settlements. Moreover, the greatest need for preventive measures applies to persons of child and adolescent age, as well as pregnant and lactating women [6]. When developing supplementation programs, it is important to take into account individual characteristics and to select the most optimal dose or mode of use of the microelement preparations $[7,8]$. To do this, one should be able to identify the most important factors that can influence the dynamics of the main indicators of the thyroid function, and also predict the expected outcome of long-term supplementation $[9,10]$.

\section{Aim of the research}

To carry out a clinical and anamnestic examination of the child's contingent of the mountain region for the detection of physical development disorders, visual-palpation examination of the thyroid gland, followed by the development of a model of multifactorial dependence of thyroid status disorders.

\section{Materials and methods}

In order to meet the set goals, a preventive survey was carried out for children (187 children) aged 13 to 17 years old living in an ecologically dependent biogeochemical endemic zone of iodine deficiency in the mountainous region of Transcarpathian region during the period of 2014 through 2015 in order to detect violations in the functioning of the thyroid gland with the following somatic effects and taking into account its morphological functional changes. The study group consisted of children aged 13 to 17 years old (mean age 15.90526 \pm 1.36$)$, among them 96 boys $(63.0 \pm 4.18 \%)$ and 81 girls $(37.0 \pm 5.06 \%$.) Clinical and anamnestic examination of the child's contingent was carried out. To identify the pathology of the thyroid gland, a visual-palpation method of examination was used according to the WHO/MRKIDZ methodology, 2001 [11]. The research was conducted on the basis of the city children's clinical hospital in Uzhhorod, Transcarpathian region. According to our data, 80 pupils $(42.8 \%$ ) had an increased thyroid gland of 1 degree, they were allocated for further and detailed examination and identification of ecologically determined somatic effects. The average height of adolescents was $166.22 \pm 1.26$ from 196 to 158 (boys 175.96 \pm 0.37 from 196 to $159 \mathrm{~cm}$ and $161.55 \pm 0.72$ in girls from 166 to $158 \mathrm{~cm})$, which corresponds to 50 centiles, regardless of sex, body weight $-57.78 \pm 1.19$ from 88 to $46(62.89 \pm 1.37 \mathrm{~kg}$ from 88 to 47 in boys and $52.49 \pm$ $\pm 1.13 \mathrm{~kg}$ from 56 to 46 in girls) corresponding to 25 centiles in children, boys and girls. A cohort of 59 adolescents living in an area with endemic iodine deficiency was investigated. 30 of them had hypertrophic changes in thyroid parenchyma, whereas in 29 adolescents parenchyma of the thyroid gland was under reference. In the dynamics, a number of indicators of serum blood and urine were determined [(free thyroxine (T4) and triiodothyronine (T3), thyrotropin (TSH), cortisol, titre of antibodies to thyroid peroxidase (AT-TPO) and to thyroglobulin (AT-TG), thyroxine-binding globulins level (TBG), tyrosine, microelements of iodine and selenium, ferritin, $\operatorname{IgM}, \operatorname{IgG}$, cholesterol, high density lipoprotein (HDL) and low (LDL), triglycerides, bilirubin, alanine aminotransferase (ALT), aspartate aminotransferase (AST), haemoglobin and the erythrocyte sedimentation rate (ESR)] [12]. All listed indicators, as well as the age and condition of the parenchyma (diffuse changes in the thyroid gland or unchanged pelvic syndrome) were studied as possible predictors of the TSH and T4 dynamics as a result of supplements. Preventive measures included the administration of the dietary supplement Yosen manufactured by “OmniFarm” LLC, TU U 10.8-35758392-004: 2014 according to generally accepted recommendations for supplements [13]. Doses were prescribed according to the instructions and age requirements of 1 tablet once a day during meals, drinking water for 6 months. Materials of scientific and practical work were considered at a meeting of the Bioethics Commission. The safety rules of the investigated contingent and the patient's rights were observed. During conducting of scientific and practical investigations of violations of moral and ethical norms in relation to patients was not revealed. The question was formulated as follows: "Is it possible to predict with a satisfactory accuracy the dynamics of the indicator of the thyroid function 
under iodine and selenium supplementation, using biochemical parameters?". The accuracy of the forecast, which corresponds to the determination coefficient $\mathrm{R}^{2} \geq 0.5$, was considered satisfactory, which is twice (or more than twice) less than the mean square error than with pure guessing. Statistical simulation was carried out in the software environment for statistical calculations R 3.4.3. A flexible and modern algorithm for multivariate adaptive regression splines (MultivariateAdaptiveRegressionSplines, MARS) [14, 15] was used to construct regression prediction models.

The MARS algorithm creates an additive nonlinear model, which is described by the following equation.

$$
\hat{y}=a_{0}+\sum_{m=1}^{M} a_{m} B_{m}(x),
$$

where $\hat{y}$ - the predicted value of the dynamics, $a_{0}$ - the intercept, $\mathrm{M}$ is the number of basic functions, $B_{m}$ and $a_{m}$ are the m's basic function and its coefficient. Each basic function, in turn, is a power function, which is described by the following equations:

$$
\begin{aligned}
& {[+(x-t)]_{+}^{q}= \begin{cases}(x-t)^{q}, & \text { if } x \geq t, \\
0, & \text { in other case, }\end{cases} } \\
& {[-(x-t)]_{+}^{q}= \begin{cases}(t-x)^{q}, & \text { if } x<t, \\
0, & \text { in other case, }\end{cases} }
\end{aligned}
$$

where $t$ is the coordinate of the node, and $\mathrm{q}(\geq 0)$ is the spline power [16]. The construction of MARS models goes in two stages: direct and reverse. In the direct phase, the factors are involved in the model for the "greedy" principle, so that an overfitted model is formed. In the next, this model is simplified and improved during the reverse phase. The MARS algorithm is configured with the nprune hyperparameters, which corresponds to the maximal number of components (predictors + free member) in the model after simplification, and $q$, which is a spline power. In this study, an algorithm with hyperparameters nprune $=\{2: 10\}$ and $q=\{1 ; 2\}$ was tested by an exhaustive analysis of all pairwise combinations of hyperparameters. The criterion for choosing the best combination of hyperparameters was the mean-square error (in fact, its square root) of leave-one-out crossvalidation. To evaluate the predictive power of the models, a separate test sample was used, which was constructed by randomization method before simulation. In this study, the size of the test sample was set at the level of 6 people, the training sample -53 people. To determine the probabilistic nature of the received models, the response permutation test was carried out. During this test, the value of the dependent variable was randomly mixed, and thereafter, a complete cycle of constructing the model was carried out, which included the selection of hyperparameters and fixation of the obtained random variable determination. After 100 iterations of such a procedure, the set of determination coefficients for random models was compared with the determination coefficient of the original model. The test was considered successful if there were less than 5 cases of exceeding the value of the determination coefficient of the original model by the indices of 100 random models. This corresponds to the established $\mathrm{p}<0.05$.

\section{Results}

\section{Model of the dynamics of TSH with supplementation of iodine and selenium}

Among the studied adolescents, the initial level of TSH in the thyroid gland hyperplasia group was $2.87 \pm 0.67 \mathrm{mMol} / \mathrm{l}$, whereas in the group with normal thyroid parenchyma the TSH mean was lower $(1.89 \pm 0.43 \mathrm{mMol} / \mathrm{l})$. The values of TSH levels according to the authors $[17,18]$ in children with thyroid hyperplasia corresponded to the level of "normally high", when in patients with normal thyroid parenchyma - it corresponded to the "optimal" level. After 6 months of supplements with iodine and selenium, the TSH level decreased in both groups, the dynamic in the group with diffuse thyroid changes was more pronounced (mean $-0.54 \pm 0.37 \mathrm{mMol} / 1$ compared to $-0.13 \pm$ $\pm 0.42 \mathrm{mMol} / 1$ in the group with normal thyroid parenchyma). 
Optimization of root mean square error (RMSE) over the field of hyperparameters values allowed to find the minimum error model with spline power $q=1$ and the number of components in the model nprune $=3$ (Fig. 1, a). For this model, the determination coefficient $\mathrm{R}^{2}=0.45$, the results of crossvalidation correspond to $\mathrm{Q}_{\mathrm{LOO}}^{2}=0.35$, the predictive power determined on the test sample is $\mathrm{R}_{\text {ext }}^{2}=0.58$. Comparison of predicted and actual values of TSH dynamics showed that the model does not predict an increase in TSH in the process of supplementation, whereas in some adolescents some increase in TSH has been observed (Fig. 1, b). The response permutation test revealed 2 cases of exceeding the determination coefficient of the original model by its random counterparts. Taking into account that 100 random replicas were constructed during the test, the p-value of the original model is at the level of $\mathrm{p}=0.02$.

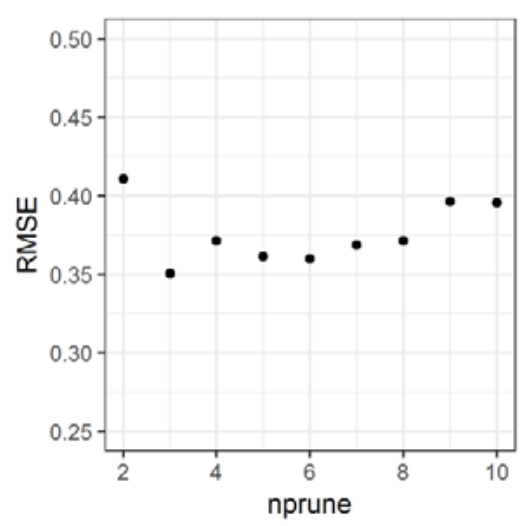

$a$

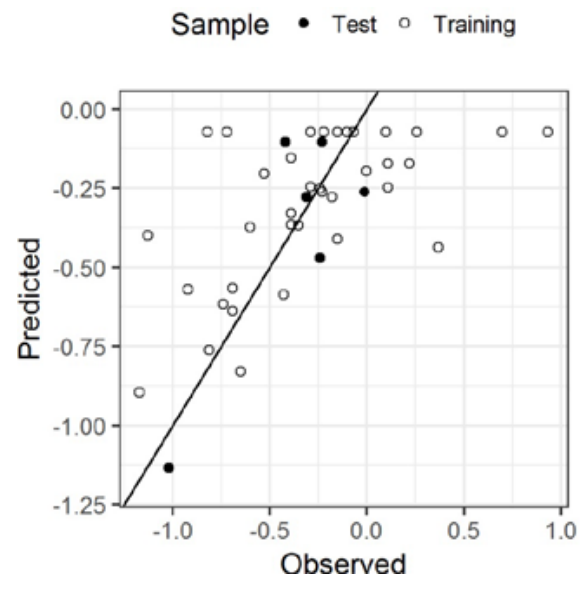

$b$

Fig. 1. Visualization of model errors for predicting the dynamics of TSH under supplementation with iodine and selenium: $a$ - error of crossvalidation with different values of nprune hyperparameter; $b$ - comparison of predicted and observed values of TSH dynamics

As a result of the modeling with MARS algorithm, the level of AT-TPO and urinary iodine content were found as necessary and sufficient predictors. That is, the introduction of any additional predictors from the array of the biochemical parameters we investigated adds nothing to the predictive value. In addition, after taking into account the levels of AT-TPO and iodine in urine, the differentiation of adolescents in the state of thyroid parenchyma (hyperplasia, norm) has no predictive value for determining the dynamics of TSH. The formula for prediction is as follows:

$$
\Delta(\mathrm{TSH})=-0,0728-0,0734 \times h(10,21-[\mathrm{AT}-\mathrm{TPO}])-0,0173 \times h(41,40-[\text { Iodine in urine }]),
$$

where $h$ denotes the so-called "hinge" function. The essence of its work on the example of AT-TPO is as follows: if the level of AT-TPO is less than $10.21 \mathrm{mMol} / \mathrm{ml}$, then the difference in the argument of the "hinge" function will be a positive number, and the value of the function will be this difference. If the AT-TPO level is greater than $10.21 \mathrm{mMol} / \mathrm{ml}$, then the difference will be a negative number and the function value will be zero.

As a result, the characteristic of the influence of AT-TPO on $\Delta(\mathrm{TSH})$ is as follows: at low levels of AT-TPO $(<10.21 \mathrm{mMol} / \mathrm{ml})$, the decrease in TSH due to supplements will be more pronounced, and the lower the level of AT-TPO, the better will be the decrease of the level TSH; if the AT-TPO level is higher than $10.21 \mathrm{mMol} / \mathrm{ml}$, then this component will not have an effect on the dependent variable, which means that the TSH dynamics will be projected at a displacement level corresponding to a slight decrease of $-0,0728 \mathrm{mMol} / 1$. Thus, this component regression model takes into account the following feature: a marked decrease in TSH in response to supplements with iodine and selenium is possible only with sufficiently low values of AT-TPO, which means the absence of autoimmune causes of thyroid homeostasis. At high levels of AT-TPO, significant 
changes in TSH due to supplementation are not meaningful. The quantitative interpretation of this feature was embodied in the regression model due to automatic analysis by the MARS algorithm of the collected data.

A similar pattern of influence was also demonstrated by a predictor such as the concentration of iodine in the urine. So, with an excess of this indicator of $41.40 \mu \mathrm{mol} / 1$, the decrease in TSH level due to supplementation is practically non-existent. However, with values of iodine concentration in urine less than $41.40 \mu \mathrm{mol} / 1$, the positive effect of supplementation increases, and the less the iodine content in the urine will be, the stronger will be the lowering of TSH in the background of iodine and selenium-containing drug administration. This effect has a natural explanation: at a sufficient level of iodine intake, its concentration in the urine will be relatively high, and the effect of supplements with iodine will be absent. Iodine deficiency will primarily be manifested in reducing the elimination of iodine in urine - and in such cases, the additional intake of this micronutrient will contribute to the normalization of thyroid status. The influence of identified predictors on the dynamics of TSH in the training sample is visualized in Fig. 2

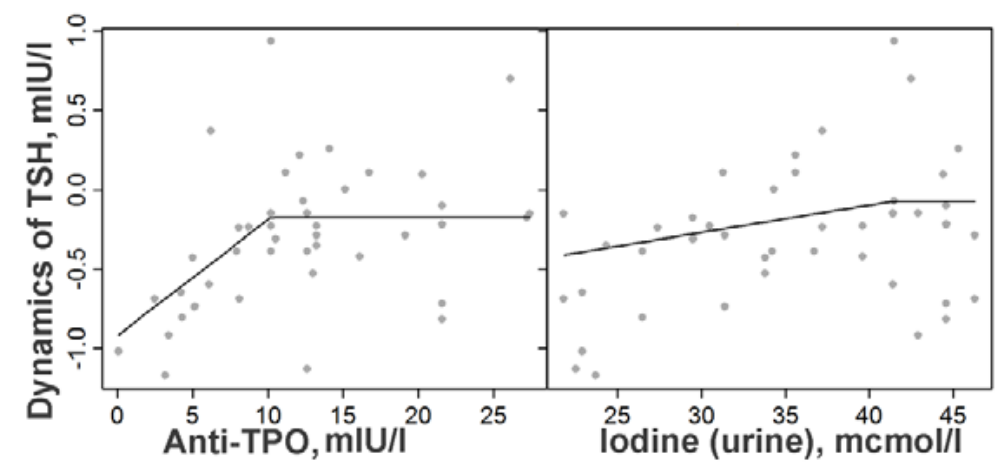

Fig. 2. Graphic representation of the effect of identifiable predictors in the developed regression model for forecasting the dynamics of TSH

The predictive value of the model on the test sample is in the acceptable range $\left(\mathrm{R}_{\text {ext }}^{2}=0.58\right)$, statistics on the accuracy of the model $\mathrm{R}^{2}=0.45$ and $\mathrm{Q}_{\mathrm{LOO}}^{2}=0.35$ are in the range of averages.

\section{Discussion}

The state of the child organism in the endemic zone of iodine deficiency undergoes constant ecologically unfavourable influence. Target body is thyroid gland. Thyroid hormones affect the level of many parts of the homeostasis. The compensatory mechanism of the child's body in conditions of iodine deficiency is an increase in the size of the thyroid gland, which is aimed at supporting the hormonal exchange of the gland and as a consequence - the development of minimal thyroid deficiency with the further development of subclinical hypothyroidism. This condition is increasingly identified by scientists and requires additional research to prevent its development. The increase in the size of the thyroid gland causes a scientific discussion on the subject of the presence of a medical problem - when the onset of minimal thyroid failure [19, 20]. The scientific literature gives a definition of this pathological condition that coincides with the initial stage of subclinical hypothyroidism and is represented by the reference values of thyroid hormones at the level of TSH in the range of 2.5-4.0 mMol/1 [8, 16]. We determined the levels of TSH, T3, T4 hormones and calculated the TSH / FT4 indices, the integral thyroid index of ITI (FT3+FT4)/TSH), which give the opportunity to correctly assess the thyroid status of the child. The minimum thyroid dysfunction according to our data was observed in hyperplasia of the thyroid gland, and with unchanged parenchyma observed - euthyroid state. The values of TSH levels according to the authors [17, 18] in children with thyroid hyperplasia corresponded to the level of "normally high", when in patients with normal thyroid parenchyma - it corresponded to the "optimal" level. Therefore, in predicting using this model, one should also take into account a clinical decision that characterizes the patient's condition in association with additional accompanying features in conjunction with the 
ultrasonographic examination of the thyroid gland and the use of the TSH/FT4 indices, the integral thyroid index ITI (FT3+FT4)/TTSH)

\section{Conclusions}

1. Changes in the level of TSH when supplemented with iodine and selenium are dependent on the initial values of the titre of antibodies to thyroid peroxidase and the content of iodine in the urine.

2. The degree of positive changes (decrease of TSH, increase of T4) with supplements with iodine and selenium depends on the starting content of micronutrients of iodine in plasma of blood and/or urine: the lower the initial level of iodine availability, the more pronounced is the effect of supplements.

3. The developed statistical model for forecasting the dynamics of TSH and T4 (free) when supplemented with iodine and selenium provides prediction of T4 and dynamics is characterized by proper accuracy and prognostic ability and is recommended for further use.

4. The predictive value of the model on the test sample is in the acceptable range $\left(\mathrm{R}_{\text {ext }}^{2}=0.58\right)$, the statistics on the accuracy of the model $\mathrm{R}^{2}=0.45$ and $\mathrm{Q}_{\mathrm{LOO}}^{2}=0.35$ are in the range of averages. Therefore, when predicting using this model, one must also take into account a clinical decision that characterizes the patient's state of the association with additional accompanying features in conjunction with the data of ultrasonographic examination of the thyroid gland [21].

\section{References}

[1] Berzin, V. I., Shchudro, S. A. (2011). Zdorovya ditey ta pidlitkiv: hihiyenichni ta psykhofiziolohichni aspekty. Skhidnoievropeiskyi zhurnal hromadskoho zdorovia, 1, 60-61.

[2] Benua, B., Berrou, D., Delanzhe, F. et. al. (2008). Otsiniuvannia yododefitsytnykh zakhvoriuvan ta monitorynh yikh usunennia. Kyiv: K.I.S, 95.

[3] Rusakov, N. V., Zavystyaeva, T. Yu. (2006). Geokhimicheskie provintsii strany i zdorov'e naseleniya. Gigiena i sanitariya, 5, 100-102.

[4] Trush, O. A. (2010). Likvidatsiia yododefitsytu v Ukraini - problema sotsialno-ekonomichnoho znachennia. Endokrynolohiia, 13 (2), 347.

[5] Tronko, M. D., Polumbryk, M. O., Kravchenko, V. I., Balon, Ya. H. (2011). Naukovi aspekty vyrishennia problem yododefitsytu u naselennia Ukrainy. Endokrynolohiia, 16 (2), 189-199.

[6] Horlenko, O. M., Pushkash, L. Yu., Deviniak, O. T. (2017). Obstezhennia pidlitkovoho kontynhentu ekolohichno zalezhnoho hirskoho rehionu. Visnyk Uzhhorodskoho universytetu. Seriia «Medytsyna», 2 (56), 102-110.

[7] Turchyna, S. I. et. al. (2015). Alhorytm obstezhennia i tekhnolohiia likuvannia ditei iz dyfuznym netoksychnym zobom, shcho meshkaiut v umovakh lehkoho yododefitsytu. Metodychni rekomendatsii. Ukrainskyi zhurnal dytiachoi endokrynolohii, 3-4, 58-66.

[8] Zelinska, N. B., Reznikova, A. L., Mamenko, M. Ye., Yerokhina, O. I. (2006). Zob u ditei; klinika, dyferentsiina diahnostyka, likuvannia (Metodychni rekomendatsii). Suchasna pediatriia, 1 (10), 57-66.

[9] Pankiv, V. I. (2013). Endemichnyi zob (yododefitsytni zakhvoriuvannia). Novosty medytsyni y farmatsyi, $8,28-31$.

[10] Burman, K. D. (2012). Thyroid Disorders and Diseases. Medical Clinics of North America, 96 (2), 98-108. doi: 10.1016/j.mcna.2012.02.004

[11] WHO, UNICEF, and ICCIDD. Assessment of the Iodine Deficiency Disorders and monitoring their elimination (2001). Geneva: WHO, WHO/Euro/NUT, 1-107.

[12] Kamyshnikov, V. S. (Ed.) (2016). Metody klinicheskikh laboratornykh issledovaniy. Moscow: MEDpress-in form, 736.

[13] WHO, UNICEF, and ICCIDD. Assessment of the Iodine Deficiency Disorders and monitoring their elimination (2007). Geneva: WHO, WHO/Euro/NUT, 1-98.

[14] Friedman, J. H. (1991). Multivariate Adaptive Regression Splines. The Annals of Statistics, 19 (1), 1-67. doi: 10.1214/aos/1176347963

[15] Earth: Multivariate Adaptive Regression Splines. R package version 4.6.0. Available at: https:// CRAN.R-project.org/package=earth/ 
[16] Deviniak, O. T., Lesyk, R. B. (2013). Doslidzhennia zviazku mizh strukturoiu 4-tiazolidynoniv ta yikh protypukhlynnoiu aktyvnistiu za dopomohoiu bahatovymirnykh adaptyvnykh rehresiinykh splainiv. Zhurnal orhanichnoi ta farmatsevtychnoi khimii, 10 (4 (40)), 76-82.

[17] Turchyna, S. Y. (2013). Diffuznyy netoksicheskiy zob i polovoe sozrevanie. Ukrainskyi zhurnal dytiachoi endokrynolohii, 1, 23-28.

[18] Kravchun, N. A., Chernyavskaya, I. V. (2011). Gipotireoz: epidemiologiya, diagnostika, opyt lecheniya. Problemy endokrynnoi patolohii, 3, 27-34.

[19] Zimmermann, M. B., Molinari, L., Spehl, M., Weidinger-Toth, J., Podoba, J., Hess, S., Delange, F. (2001). Updated Provisional WHO/ICCIDD Reference Values for Sonographic Thyroid Volume in Iodine-Replete School-age Children. IDD Newsletter, 17 (1), 12.

[20] Shilin, D. Ye. (2002). Aktual'nyye voprosy laboratornoy diagnostiki zabolevaniy shchitovidnoy zhelezy (sovremennyye rekomendatsii mezhdunarodnykh organizatsiy. Laboratoriya, 3, 22-26.

[21] Zimmermann, M. B., Hess, S. Y., Molinari, L., de Benoist, B., Delange, F., Braverman, L. E. et. al. (2004). New reference values for thyroid volume by ultrasound in iodine-sufficient schoolchildren: a World Health Organization/Nutrition for Health and Development Iodine Deficiency Study Group Report. The American Journal of Clinical Nutrition, 79 (2), 231-237. doi: 10.1093/ajcn/79.2.231

\title{
RESEARCH OF CERTAIN PATHOGENIC CHARACTERISTICS OF CLINICAL ISOLATES OF STAPHYLOCOCCI OF SKIN BIOME
}

\author{
Yanina Kutasevych \\ Director \\ $S E$ «Institute of Dermatology and Venerology of National Academy of Medical Sciences of Ukraine» \\ 7/9 Chernyshevka str., Kharkiv, Ukraine, 61057 \\ Svetlana Dzhoraeva \\ Laboratory of Microbiological \\ $S E$ «Institute of Dermatology and Venerology of National Academy of Medical Sciences of Ukraine» \\ 7/9 Chernyshevka str., Kharkiv, Ukraine, 61057 \\ Valentina Goncharenko \\ Laboratory of Microbiological \\ $S E$ «Institute of Dermatology and Venerology of National Academy of Medical Sciences of Ukraine» \\ 7/9 Chernyshevka str., Kharkiv, Ukraine, 61057 \\ Yuliia Shcherbakova \\ $S E$ «Institute of Dermatology and Venerology of National Academy of Medical Sciences of Ukraine» \\ 7/9 Chernyshevka str., Kharkiv, Ukraine, 61057 \\ Viktoriya Mangusheva \\ Department of dermatology, infectious and parasitical of skin disease \\ $S E$ «Institute of Dermatology and Venerology of National Academy of Medical Sciences of Ukraine» \\ 7/9 Chernyshevka str., Kharkiv, Ukraine, 61057

\section{Nataliya Sobol \\ Laboratory of Clinical} \\ $S E$ «Institute of Dermatology and Venerology of National Academy of Medical Sciences of Ukraine» \\ 7/9 Chernyshevka str., Kharkiv, Ukraine, 61057
}

